\title{
PERSEPSI PEREMPUAN MENGENAI BERITA WACANA PELEGALAN POLIGAMI DI ACEH
}

\author{
Putri maulina, Reni Juliani \\ Universitas Teuku Umar Meulaboh
}

\begin{abstract}
In 2019, the government of Aceh and the Regional People's Representative Assembly (DPRA) drafted a Family Law Qanun which will be ratified and applied in Aceh. One of the contents of the chapter in the Qanun is legalizing polygamy. This discourse attracted the attention of the general public after Serambi Indonesia daily published it as a headline in the 6th July 2019 edition. With regard to the pros and cons of the discourse on the legalization of polygamy in Aceh, women's voices are considered important in addressing this qanun. Given that the design of the qanun is based on providing solutions to the protection of women. The pros and cons of the discourse on the legalization of the qanun on polygamy also arise on the basis of concerns about the party system that is still in force in this country. The patriarchal system that dominates culture encourages the formation of gender disparities and injustices where women are positioned as subordinates while the position of men is to hold more control. This is what makes women's voices weak in society. The purpose of this research is to dig deeper into women's perceptions about the discourse on the legalization of polygamy in Aceh using the conceptual approach of Perception and Spiral of Silence Theory. This research uses mixed methods by distributing questionnaires and interviews. The results showed the diversity of perceptions among women in responding to the discourse on legalizing polygamy. The perception of women in Aceh tends to show a uniform meaning that views polygamy as something that can be done but not a solution to the problem of marriage in Aceh.
\end{abstract}

\section{Keywords}

(Perception, Spiral of Silence, women, News, Law of Poligamy)

Correspondence Contact putrimaulina@utu.ac.id

\section{PENDAHULUAN}

Aceh adalah salah satu provinsi di Indonesia yang diberikan wewenang untuk mengatur pemerintahan dalam bentuk otonomi khusus. Salah satu wewenang yang dimiliki oleh Provinsi Aceh adalah menjalankan pemerintahan dengan berlandaskan pada Syariat Islam. Berdasarkan otonomi tersebut pada pertengahan tahun 2019 lalu, Pemerintah Aceh mengeluarkan wacana terkait pelegalan poligami melalui Qanun Hukum Keluarga. Wacana tersebut menjadi topik yang menimbulkan pro dan kontra pada masyarakat Aceh di berbagai media sosial dan forum-forum diskusi publik, terutama setelah surat kabar lokal di Aceh yaitu Harian Serambi Indonesia memberitakan isu tersebut dalam beberapa edisi pemberitaan.

Oleh Pemerintah Aceh, pelegalan poligami dipandang sebagai salah satu alternatif untuk dapat melindungi kalangan perempuan di Aceh dari dampak pernikahan (Sohuturon, 2019) yang merujuk pada fakta kasus-kasus pernikahan di Aceh terutama berkaitan dengan angka perceraian. Dalam hal ini Badan Pusat Statistik Aceh(BPS) pada 2019 telah 
mencatatditemukan 5.928 kasus perceraian (1.533 cerai talak dan 4.395 cerai gugat). Sedangkan di sisi lainnya Mahkamah Syar'iyah Aceh juga memberikan data angka perceraian dan kasus sengketa perceraian pada 2019 mencapai 6.700 dan $90 \%$ di antaranya telah dianggap selesai dan ditetapkan oleh pengadilan (www.aceh.tribunnews.com, 27 Juli 2020). Beranjak dari dasar tersebut, pemerintah merumuskan kebijakan dalam rancangan qanun keluarga untuk dapat melegalkan poligami sebagai bentuk solusi terhadap pernikahan dan perceraian.

Sejalan dengan rencana pelegalan hukum poligami di Aceh tersebut, pada dasarnya Harian Serambi Indonesia menjalankan fungsi pengawasan media terkait kebijakan yang diwacanakan kepada masyarakat Aceh. Melalui pemberitaan, Harian Serambi Indonesia sebagai media massa memiliki power dalam mendorong opini dan persepsi publik untuk menanggapi wacana pelegalan hukum poligami di Aceh sebagai bagian dari peran media dalam mengawasi kebijakan publik. Mediamassa merupakan alat yang tepat untuk menyebarluaskan wacana dan membangun opini publik. Pro dan kontra terkait wacana pelegalan poligami di Aceh tersebut pun muncul sebagai dampak dari pemberitaan Harian Serambi Indonesia pada edis 6 Juli 2019 yang berjudul "Aceh Akan Legalkan Poligami" sebagai berita utama di halaman depan pemberitaan surat kabar tersebut. Dalam beberapa edisi berikutnya pun, pemberitaan wacana pelegalan poligami di Harian Serambi Indonesia memuat narasumber yang mewakili sudut pandang yang pro dan kontra. Pihak pro pelegalan hukum poligami adalah dari kalangan pemerintah sebagai pihak perumus kebijakan, sedangkan pihak yang kontra terhadap pelegalan hukum poligami tersebut adalah dari kalangan aktivis perempuan.

Namun selain kekuatan media untuk membentuk opini publik, Harian Serambi Indonesia sebagai media massajuga dapat melibatkan perspektif dan cara pandangnya untuk menelaah realitas sosial terkait pelegalan poligami di Aceh tersebut. Harian Serambi Indonesia dapat memilih gunamemilih aspek-aspek yang dimunculkan maupun dihilangkan, penentuan struktur berita ini disesuaikankeinginan media itu sendiri, seperti sudut pandang yang diambil untuk menyoroti suatu peristiwa, kemudian memilah bagian mana yang akan ditonolkan atau dihilangkan dari peristiwa tersebut,menentukan siapa narasumber yang diwawancarai untuk menjadi sumber berita, dan lain-lain.

Wacana pelegalan poligami yang ditampilkan di Harian Serambi Indonesia diasumsikan dapat memberikan ruang ketidakadilan terhadap perempuan sebagai pihak minoritas. Salah satu ruang ketidakadilan dalam pemberitaan media ialah dalam hal penentuan leksikal dan bahasa (simbol). Meskipun media massa berfungsi sebagai penyampai berita atau informasi, tapi harus memerhatikan pemilihan kata, istilah atau simbol yang secara konvensional yang mempunyai arti tertentu pada masyarakat, maka media dapat membentuk wacana di tengahtengah masyarakat dan melanggengkan bentuk-bentuk ideologi dominan.

Wacana poligami di mediamassa memang bukanlah hal asing. Banyak publikasi di media massa yang menyoroti permasalahan poligami, terutama yang berkaitan dengan perilaku poligaminya tokoh-tokoh publik seperti artis, pejabat, bahkan kalangan agamawan. Seperti pada kasus poligaminya Anis Matta, AA Gym, Opick, Kiwil, Rhoma Irama dan beberapa tokoh publik lainnya yang oleh media massa diberitakan secara bombastis dan berlebihan.Sehingga dari pemberitaan-pemberitaan di media massa, konsep poligami menjadi hal yang lumrah ditemukan di tengah-tengah masyarakat. Namun demikian, substansi pemberitaan di media massa cenderung menekankan pada praktik dari poligami itu sendiri dan kurang berfokus pada bagaimana sudut pandang dari perempuan sebagai objek dari poligami. 
Persepsi perempuan terkait wacana pelegalan poligami di Aceh yang diberitakan oleh Harian Serambi Indonesia dipandang perlu untuk dikaji. Sebagai objek dari poligami, perempuan tentu memiliki cara pandang yang berbeda dalam memaknai hukum poligami tersebut. Keberagaman persepsi perempuan dalam memaknai poligami kurang terpublikasikan dalam pemberitaan-pemberitaan media, sehingga persepsi atas pelegalan poligami cenderung dimaknai dalam sudut pandang mayoritas terutama sudut pandang laki-laki yang menjadi pemangku kebijakan.

Adapun penelitian ini mempunyai tujuan untuk memberikan jawabantentang bagaimana wacana kebijakan pelegalan poligami di Aceh yang ditampilkan di media dipersepsikan oleh kaum perempuan di Aceh Barat sebagai kelompok minoritas. Terdapat faktor-faktor yang dapat mempengaruhi persepsi perempuan dalam menanggapi wacana poligami tersebut, seperti keberagaman latar belakang, kondisi sosial budaya, pengalaman, pemahaman agama, atau dasar kerangka rujukan.

\section{KAJIAN TEORITIK}

\section{Konsep tentang Persepsi}

Individu merupakan salah satu objek dari kajian komunikasi yang memiliki persepsi. Persepsi (perception) merupakan pengalaman tentang objek, peristiwa, atau hubungan-hubungan yang didapatkansuatu individu dalam proses komunikasi dengan meresume informasi dan melakukan penelaahan pesan. Menurut Rakhmat (2011:50) persepsi merupakanmemberikan makna pada stimulus inderawi (sensory stimuli). Sedangkan menurut Boyd, Walker dan Larreche dalam Fadila dan Lestari(2013:45), persepsi merupakantahapan yang dimiliki seseorangsaat memilih, mengatur dan menginterprestasikan informasi.Dalam proses persepsi, bukan sajamengikutsertakan sensasi, tetapi juga atensi, ekspektasi, motivasi, dan memori (Desiderato, 1976:129).Persepsi dilandaskan darifaktor personal dan faktor situasional. Oleh David Krech dan Richard S. Crutchfield (1977: 235) disebut sebagai faktor fungsional dan faktor struktural.

Menurut Schiffman dan Kanuk (2008:137) persepsi sebagai tahapan dilakukan seseorang untuk menyeleksi, menyusun dan menelaah rangsangan dalam bentuk gambar yang memiliki makna tertentu dan masuk akal mengenai dunia. Dua orang mungkin menerima rangsangan yang sama dalam kondisi nyata yang serupa, namun bagaimana setiap orang mengenal, menyeleksi, menyusun dan menelaahnya adalah proses yang sangat individual berdasarkan kebutuhan, nilai-nilai dan harapan setiap orang itu sendiri.

Menurut Toha (2004:154) terdapat dua macam persepsi yaitu :

a.) External perception, ialah persepsi yang disebabkan oleh rangsangan yang datang dari luar diri seseorang.

b.) Self perception, ialah persepsi yang disebabkan olehrangsangan yang berasal dari dalam diri seseorang.

Dalam konteks kajian ini, kalangan perempuan di Aceh dapat mempersepsikan wacana pelegalan poligami berdasarkan persepsi eksternal dan internal yang dimiliki. Juga berdasarkan dorongan-dorongan dari pengaruh faktor situasional dan personal. 


\section{Spiral of Silence}

Dalam mengkaji opini khalayak atas suatu wacana di media, salah satu pendekatan yang dapat digunakan adalah spiral keheningan (spiral of silence). Media massa dalam penekanan teori ini menjadi pihak yang menyuarakan suara mayoritas, dan khalayak dalam bagian tertentu lebih memilih untuk bersikap 'hening' untuk mengikuti kecenderungan opini yang diberitakan oleh media.

Opini masyarakat yang tidak tersuarakan di media dalam konteks kajian komunikasi dapat ditelaah agar memberikan suara yang berbeda dari apa yang ditampilkan di media massa. Terutama dalam menanggapi wacana pelegalan poligami di Aceh, khalayak yang tidak disuarakan oleh media memiliki kecenderungan opini yang 'tersembunyikan'.

Dengan pendekatan spiral of silence, wacana pelegalan poligami dalam tataran opini khalayak dapat dikaji melalui penekanan pada karakteristik; 1) pengetahuan. Apakah isu tersebut telah menyebar dan diketahui oleh masyarakat ataupun belum. Apabila isu tersebut hanya diketahui oleh sebagian kecil masyarakat (bersifat elitis) maka dapat dikatakan bahwa teori spiral kesunyian tidak dapat dibuktikan; 2)kedekatan terhadap isu. Apakah suatu isu tersebut dekat dan erat kaitannya dengan kehidupan sehari-hari seseorang. Teori spiral kesunyian besar kemungkinan dapat dibuktikan apabila isu yang dimaksudmempunyai kaitan dengan kehidupan sehari-hari seseorang. 3)prediksi opini. Apakah seseorang mampu memprediksikankecenderungan opini yang muncul di tengah masyarakat dengan tepat. Teori spiral kesunyian besar kemungkinan dapat dibuktikan ketika orang mampu memperkirakan opini dominanyang berkembang di dalam masyarakat (Eriyanto, 2012: 20).

\section{Hukum Tentang Poligami}

Secara etimologis, istilah poligami bersumber dari kataapolusdalam bahasa Yunani yang memiliki arti banyakdan gamos yang bermakna istri atau pasangan,yaitu memiliki lebih dari satu pasangan (istri atausuami) dalam waktu yang sama (Ahmad, 2013: 58). Poligami didefinisikan sebagai suatu sistem pernikahan dimana seseorang dapat memiliki lebih dari satu istri/istri dalam kehidupan pernikahannya. Poligami mempunyai dua jenis, yaitu poligini dan poliandri. Poligini diartikan seorang laki-lakimelakukan pernikahan dengan lebih dari satu istri, sedangkan poliandri kebalikan dari Poligini dimana seorang perempuan dapat memiliki lebih dari satu suami.Poligami bagi laki-laki dalam Islam hukum dasarnya adalah 'mubah' atau diperbolehkan, sedangkan diharamkan secara mutlak bagi kalangan perempuan untuk memiliki lebih dari satu suami dalam waktu yang sama. Hal ini merujuk pada firman Allah SWT dalam suratAn- Nisa' ayat 3:

"Maka kawinilah wanita-wanita (lain) yang kamu senangi: dua, tiga atau empat. Kemudian jika kamu takut tidak akan dapat berlaku adil, maka (kawinilah) seorang saja, atau budak-budakyang kamu miliki, yang demikian itu adalah lebih dekat kepada tidak berbuat aniaya." (QS Al- Nisa (4) : 8)

Lebih lanjut, ulama-ulama memiliki penafsiran tentang konsep poligami tersebut (Zuhra, 2019: 29-30) :

1.) Poligami merupakan bentuk ibadah yang sifatnya mubah (boleh) dan bukan hal yang wajib. Sehingga laki-laki diperbolehkan untuk mempunyai lebih dari satu pasangan (monogami) atau lebih dari satu (poligami);

2.) Dilarangmenikah dengan lebih dari empat istri dalam waktu yang sama; 
3.) Laki-laki yang melaksanakan poligami wajib berlandaskan pada keadilan dan mampu mengimplementasikan secara yakin prinsip tersebut baik secara lahiriah dan batiniah;

4.) Batasan untuk berlaku adil dalam konteks perasaan atau cinta, dianggap hal yang di luar batas kemampuan manusia sehingga mustahil dilakukan. Sehingga konteks adil dapat ditoleransi dengan tidak berlaku dzolim pada istri-istrinya;

5.) Laki-laki yang berpoligami diharuskan untuk mampu memberikan nafkah kepada istri-istrinya sebagai jaminan.

Dari berbagai tafsiran tersebut, hukum poligami mengerucut pada kesimpulan bahwa poligami hanyalah sebuah tindakan hukum yang termasuk dalam kategori ibadah ibahah (boleh), yang artinya poligami bukanlah ibadah sunah apalagi wajib. Sehingga apabila seorang laki-laki yang ingin berpoligami, tapi dirinya sendiri tidak yakin atas kemampuannya untuk berlaku adil dan berbuat dzolim maka tindakan poligami ini tidak dianjurkan untuk diterapkan (Al-Ghazaly, 2006: 133).

Dalam konteks hukum Indonesia, aturan dan pembatasan praktik poligami secara ketat diatur dalam kebijakan meskipun dalam hukum positifnya tidak secara jelas diatur pelarangannya. Salah satu hokum yang mengatur tentang poligami dapat dilihat dari Undang-Undang No. 1 tahun1974 pasal 3 ayat 1 yang menjelaskan tentang asas monogomi perkawinan nasional danpasal 3 ayat 2 tentang persayaratan-persyaratan yang cukup ketat bagi orang yang akanmelakukan poligami (Darmawijaya, 2015: 27).

\section{METODOLOGI}

Dalam kajian ini yang menjadi subjek penelitian adalah kalangan perempuan di Aceh Barat dan objek penelitian adalah persepsi perempuan terhadap wacana pelegalan poligami Aceh Barat. Penelitian inimenggunakan pendekatan mix methods, yaitu dengan melakukan pengumpulan data melalui survey sederhana melalui media sosial terhadap kalangan perempuan di Aceh Barat untuk melihat data objektif terkait persepsi perempuan terhadap pelegalan poligami dan wawancara terhadap lima informan penelitian untuk mendapatkan informasi yang lebih mendalam terhadap perspektif perempuan dalam memaknai wacana pelegalan poligami di Aceh.Penelitian ini memakai model Miles dan Huberman untuk menganalisis data dengan cara melakukan penyusunan data, reduksi data dan melakukan resume data sehingga didapat suatu kesimpulan.

\section{HASIL DAN PEMBAHASAN}

\section{Poligami dan Subordinasi Perempuan dalam Budaya Patriarki}

Patriarki sering dipakai dalam ilmu-ilmu sosial, konsep tersebut biasanya kerap ditemukan dalam studi Antropologi dan referensi feministas. Konsep ini ditelaah sebagai suatu pandangan dimana laki-laki lebih memiliki power daripada perempuan. Laki-laki dipandang mempunyai lebih banyak keunggulan, sebagai contoh dalam memutuskan silsilah keluarga dan keturunan (keturunan patrilineal eksklusif dan menggunakan nama belakang), wewenang anak sulung, kekuasaan yang dimiliki dalam hubungan sosial, pelibatan diridi dalam masyarakat, politik dan agama. Pandangan tersebut menegaskan bahwa kodrat perempuan sebagai pengabdi kepada laki-laki. Seperti yang dijelaskan bahwa kaum perempuan dan laki-laki mempunyai perbedaan yang signifikan dalam pengembangan sifat dan karakter. Laki-laki ditakdirkan telah mempunyai sifat dominan yang kuat, keras, butuh penghargaan, penghormatan dan kewibawaan, berani, lugas dan memiliki komitmen yang tinggi. Sedangkan perempuan bersifat lemah, gemar dipuji, suka mempercantik diri, telaten, gemar akan keindahan,penyayang dan mencintai (Israpil, 2017: 143). 
Ketika konsep patriarki tersebut diterapkan di dalam masyarakat, konsep tersebut akan mempengaruhi segala aspek yang ada di dalam masyarakat seperti sistem agama dan politik serta adat istiadat yang berlaku selama ini. Perilaku manusia yang terpengaruhi oleh konsep tersebut akan berubah baik dari segi pandangan hidupnya dan bagaimana mereka memperlakukan orang lain terutama dari segi gender. Konsep patriarki yang sudah menyebar ke seluruh masyarakat melahirkan budaya patriarki yang nantinya akan diwariskan kepada penerus dari suatu generasi.

Budaya patriarki mempunyai artian bahwa suatu budaya dimana laki-laki memiliki peranan lebih dominan. Mereka dianggap berkedudukan lebih atas dari perempuan. Dalam budaya ini, terdapat perbedaan yang nyata seperti dari segi tugas laki-laki dan perempuan di dalam kehidupan mereka bermasyarakat, khususnya di dalam keluarga. Budaya patriarki secara telah diwariskan dari generasi ke generasiakan membuat perilaku, status dan kekuasaanyang berbeda antara laki-laki dan perempuan dalam kehidupan bermasyarakat dan hal ini menyebabkan terbentuknya hirarki gender. Laki-laki sebagai pemimpin atau kepala keluarga mempunyai otoritas antara lain mempunyai power dalam faktor ekonomi dimana laki-laki pencari nafkah di dalam keluarga, dan juga terhadap penggolongan bagian kerjadari segi seksual di dalam keluarga. Hal ini yang membuat perempuan hanya sedikit diberi kesempatan untuk terlibat pada bidang publik daripada laki-laki. Patriarki merupakan kata yang digunakan dalam mendeskripsikan sistem sosial yang menyetuskan bahwa kaum laki-laki sebagai suatu kelompok pengendali kekuasaan atas kaum perempuan (Israpil, 2017: 146). Berlandaskan atas teori menyangkut marjinalisasi perempuan dan dominasi laki-laki dapat dilihat sebagai berikut (Ambon, $2014: 51-52$ ):

1. Berawal dari keluarga telah ditentukan kewenangan khusus kepada anak lakilaki.Apabila kepala keluarga atau dalam artian ayah meninggal dunia, anak laki-laki diberikan kekuasaan untuk mengambil suatu keputusan dan diberikan power untuk berkuasa terhadap anggota keluarga lainnya serta warisan harta yang ada,

2. Adapandangan dimana perempuan diperuntukkan mengurus rumah (wilayah domestik) daripada mempunyai suatu pekerjaan tertentu di luar rumah. Hal ini dapat menghambat kesempatan mereka untuk berkembang lebih baik lagi.

3. Laki-laki mempunyai otoritas atas kepuasan seksualnya. Perempuan dituntut harus dapat melakukan layanan seksual terbaik sesuai kebutuhan laki-lakinya, dan perempuan tidak mempunyai hak untuk menyesuaikan dengan keinginannya.

4. Perempuan sering dijadikan objek seks laki-laki. Sedangkan pada saat terjadi pelecehan seksual, perempuan merupakan pihak yang bersalah apabila pelecehan tersebut dilakukan oleh laki-laki kepada mereka.

5. Pergerakan dan pemikiran perempuan dibatasi dan dikekangdalam sistem patriarkhi yang berlaku di masyarakat.

Kelima poin di atas merupakan bentuk-bentuk marjinalisasi perempuan dan kekuasaan lakilaki secara dominan. Marjinalisasi perempuan ini diakibatkan oleh kekuasaan tunggal laki-laki dalam masyarakat patriarkhi. Laki-laki mempunyai otoritas dan pengendali kekuasaan dalam masyarakat serta penentusuatu putusan atau tindakan yang terjadi pada perempuan dan seluruh masyarakat pada umumnya. Dominasi ini diterapkan pada segala aspek baik dalam keluarga sampai padalevel pemerintah. Ideologi ini menyebabkan perempuan sebagai bagian yang terpinggirkan, dinomorduakan dari makhluk Tuhan, dan menjadi objek dalam keseluruhan sistem (Ambon, 2014 :52-53).

Di dalam keluarga, masih terdapat perempuan yang tidak dibiarkan terlibat dan tidak diikutsertakan dalam hal penentuan keputusan. Perempuan bukannya tidak bisa melawan. Hanya saja, mereka tidak diberi kesempatan berpikir untuk melawan, suara perempuan adalah suara yang dibisukan. Penyebabnya karena adanya nilai-nilai yang ada pada masyarakat yang memojokkan perempuan seperti pengaruh budaya patriarki yang telah lama dianut oleh masyarakat. 
Dalam rumah tangga, suami ibarat raja dan perempuan adalah pengabdi raja yang harus memenuhi keinginan dan kemauan suami mereka, salah satunya poligami. Padahal, dilihat dari logika sederhana poligami hanya memberikan keuntungan untuk kaum laki-laki. Tetapi, penentangan akan poligami dari perempuan tidak dapat dilakukan. Hal ini dikarenakan poligami tidak diharamkan oleh agama. Sedangkan tidak ada peraturan agama yang mengatur bagaimana jika seorang perempuan mempunyai keinginan poliandri atau bersuamikan lebih dari satu suami. Legalitas agama dijadikan alat yang efektif digunakan dalam membungkam suara perempuan agar bersedia untuk dipoligami. Pendirian perempuan yang sebelumnya menentang akan runtuh dihadapkan pada tatanan sosial yang terbentuk. Sehingga, perempuan yang awalnya menolak untuk dipoligami menjadi tidak mempunyai kuasa apapun dan menerima hal tersebut sebagai pilihannya (Farid, 2017:15-16).

\section{Persepsi Perempuan Mengenai Berita Wacana Pelegalan Poligami Di Aceh}

Dalam sudut pandang kajian Teori Spiral of Silence, media massa sebagai bagian dalam proses komunikasi merupakan suatu alat yang memiliki kekuatan dalam membangun opini di tengah-tengah masyarakat. Dengan kekuatan yang dimiliki oleh media massa tersebut, media massa mempunyai fungsi sebagai alat untuk menyebarluaskan pandangan publik yang melahirkan opini atau pendapat yang dominan. Sementara di sisi lain, khalayak sebagai individu dalam menanggapi suatu wacana akan bergantung pada pandangan yang dominan. Sejalan dengan yang dijelaskan oleh Noelle-Neumann bahwa media tidak menyampaikan interpretasi secara luas dan seimbang pada suatu peristiwa yang membuat masyarakat mempunyai pandangan secara terbatas dan sempit terhadap realita.

Dalam konteks Spiral of Silence, setidaknya media massa mempunyai tiga karakteristik yang berperan untuk membentuk opini publik yaitu:

1) Ubikuitas: merujuk pada fakta. Media sebagai sumber informasi yang luas karena dapat ditemukan dimana saja, dengan kata lain, ubikuitas membentuk suatu kepercayaan dengan menawarkan fakta. Sehingga wacana poligami akan dipandang sebagai suatu fakta ataupun kebenaran.

2) Kumulatif: efek timbal balik dalam menyusun kerangka acuan. Oleh sebab itu media menjadi mengacu pada proses media yang selalu melakukan pengulangan terhadap informasi yang diberitakan. Sehingga proses mengulang-ulang informasi itu dapat menarik perhatian khalayak dan membangun persepsi publik terhadap pelegalan poligami.

3) Konsonan: Konsonan berasal ataspreferensi media untuk mempertegas atau mengkonfirmasikan pemikiran dan opini mereka sendiri dan membuat seakan pemikiran dan opini tersebut berasal dari masyarakat. Sehingga dalam konteks ini, wacana pelegalan poligami yang dibangun oleh media seakan-akan merupakan representasi dari opini masyakarat secara keseluruhan.

Media massa memiliki kekuatan dalam membentuk opini masyarakat terkait wacana pelegalan hukum poligami di Aceh. Sejak awal wacana pelegalan hukum poligami dibahas oleh pemerintah Aceh, Harian Serambi Indonesia memberitakan wacana pelegalan hukum poligami tersebut dalam beberapa edisi pemberitaan media di halaman depan dan halaman utama seperti edisi 6 Juli 2019 berjudul "Aceh Akan Legalkan Poligami" dan "Aktivis Perempuan: Raqan Poligami Jangan Cederai Rasa Keadilan dan Korbankan Perempuan", edisi 8 Juli 2019 berjudul "Mujahidah: Poligami Itu Melindungi Wanita" dan "Poligami Masih Sebatas Wacana" dengan menampilkan beberapa narasumber baik dari kalangan pemerintah dan aktivis perempuan. Pemberitaan Serambi Indonesia terkait wacana pelegalan poligami tersebut menjadi upaya media untuk menggiring wacana publik agar menempatkan isu tersebut sebagai hal yang penting untuk dibahas. 
Media memiliki kontribusi dalam spiral keheningan. Oleh media, khalayak media menjadi korban seperti yang disebut Noelle-Neumann dimana media juga mempunyai fungsi penghukum (pillory function), yaitu ketika khalayak menjadi tidak berdaya melawan media. Oleh karena itu, media lebih cenderung menyebarkan opini-opini baik secara umum ataupun tidak umum. Sehingga khalayak kerap tidak mempunyai kemampuan untuk menjelaskan asal usul dari opini yang ada di dalam benak mereka. Bingung dalam mempelajari informasi dari media dan yang khalayak pelajari dalam konteks interpersonal(Littlejohn dan Foss, 2009: 430-431).

Maka dalam kajian spiral of silence, media merepresentasikan suara-suara mayoritas dan dipandang dominan dan tidak menekankan suara minoritas sebagai pihak yang didiamkan oleh opini dominan yang muncul dalam pemberitaan media. Sebagai khalayak yang suarasuaranya tidak muncul ke permukaan media, dalam konteks kajian ini menjadi bentuk 'keheningan' khalayak. Meskipun di permukaan media opini pemerintah terkait pelegalan poligami menjadi mendominasi, tidak tertutup kemungkinan dalam keheningan khalayak terdapat opini yang berlawanan dengan apa yang terlihat. Sehingga keberagaman opini yang mungkin muncul pada khalayak, atau malah bertentangan dengan opini dominan di masyarakat dapat saja terjadi dalam keheningan tersebut dalam suatu bentuk persepsi informasi.

Secara lebih lanjut, pengaruh media massaatas pembentukan opini masyarakat mempunyai sifat yang kumulatif dan tidak selalu nyata. Apa yang diberitakan media atau dituliskan oleh jurnalis berbeda dengan opini masyarakat pada umumnya sehingga memunculkan iklim opini ganda. Dua versi realitas dapat berjalan, yaitu realitas media tentang wacana pelegalan poligami dan wacana masyarakat. Media memublikasikan opini masyarakat dan menyatakan kecenderunganopini yang menonjol. Sedangkan khalayak itu sendiri, akan mengungkapkan opini masing-masing dan tidak bergantung pada sudut pandang media. Sehingga wacana poligami tersebut akan berlanjut dalam spiral keheningan.

Dalam sudut pandang realita khalayak media, pesan yang disampaikan oleh media massa menjadi suatu stimulus yang diterima oleh khalayak yang mendorong munculnya interpretasi-interpretasi atau persepsi. Sebagai khalayak yang aktif, persepsi terhadap suatu pesan tidak diinterpretasikan secara sama. Keberagaman latar belakang yang dimiliki oleh khalayak media akan berpengaruh terhadap proses interpretasi atas pesan yang disampaikan oleh media. Begitu pula dalam mempersepsikan wacana pelegalan poligami di Aceh. Akan dipersepsikan secara berbeda oleh khalayak media, tergantung pada atensi, motivasi, kepentingan, atau ekspektasi terhadap wacana.

Menurut Kotler (1993: 219) persepsi merupakan tahapan bagaimana seseorang memilah, menyusun, dan memaknai informasi yang masuksehingga menghasilkan suatu gambaran keseluruhan yang berarti. Persepsi juga disebut sebagai suatu tahapan dalam pengelompokan dan interpretasi secara selektif. Persepsi seseorang dipengaruhi oleh beberapa faktor yaitu faktor personal (fungsional) dan faktor situasional (struktural) dari individu yang memberikan persepsi.

Terkait dengan wacana pelegalan poligami yang di Aceh pada 2019 lalu, maka dapat dilihat bagaimana kalangan perempuan mempersepsikan wacana pelegalan hukum poligami tersebut dari sudut pandang mereka. Jika merujuk pada wacana yang ditekankan di media massa, pada satu sisi pihak pro pelegalan hukum poligami menganggap bahwa poligami adalah solusi terhadap pernikahan dan dapat melindungi perempuan dari dampak perkawinan siri. Di sisi lainnya, pihak yang kontra menganggap poligami bukan menjadi solusi karena dengan diberlakukan poligami pun kekerasan dan perceraian dalam rumah tangga justru tetap terjadi. Secara lebih jauh, berdasarkan hasil penelitian yang dilakukan terhadap 
17 responden perempuan penelitian di Aceh Barat, menunjukkan keberagaman persepsi dalam memaknai wacana pelegalan poligami tersebut. Keberagaman persepsi ini dapat dipengaruhi oleh dua faktor pembentukan persepsi di atas, yaitu personal (fungsional) dan situasional (struktural).

Dari faktor fungsional, keberagaman persepsi perempuan dalam memaknai pelegalan hukum poligami di Aceh ditunjukan dengan penekanan pada latar belakang kebutuhan personal, kesiapan mental, dan frame of references (kerangka rujukan) yang dimiliki oleh responden penelitian.Dari ke 17 responden yang diteliti, sebagian besar memandang bahwa poligami tidak diharamkan dalam segi agama dan dibenarkan. Hanya saja hal ini kembali kepada kemampuan laki-laki dalam bersikap adil. Mereka menilai selama ini bersikap adil sangat sulit dan poligami yang sebenarnya ibadah apabila dilihat dari segi agama, namun dimanfaatkan dikarenakan nafsu belaka.

"Poligami menurut saya bukanlah hal yang mudah untuk dilaksanakan baik oleh pria, ataupun diterima oleh wanita. Karena pada dasarnya untuk poligami itu dilakukan bukan karena nafsu semata, tapi untuk beribadah kepada Allah. Tapi sekarang kebanyakan orang berpoligami itu karna nafsu bukan karna Allah." (AD, wawancara, 25 Agustus 2020)

Landasan agama menjadi kerangka rujukan dari sebagian besar responden dalam memaknai hukum poligami, sehingga hukum poligami pada dasarnya dipandang baik dan dapat menjadi solusi untuk menghindari maksiat dan permasalahan keluarga lainnya. Namun di lain sisi, faktor personal seperti pengalaman yang pernah dialami dari setiap responden penelitian di lingkungan mereka menunjukkan bahwa keadilan tetap harus menjadi patokan keberhasilan poligami tersebut. Karena apabila keadilan tidak dapat diterapkan, maka akan menjadi malapetaka bagi mereka. Seperti yang dinyatakan oleh beberapa pernyataan responden berikut:

"Poligami pada dasarnya baik. Artinya bisa memberikan jaminan hak perempuan dengan legalitas perkawinan baik secara agama maupun negara. Namun pada aplikasinya, terkadang masih banyak lelaki yang tidak mampu memberikan hak tersebut dengan adil dan baik kepada setiap istri." (DM, wawancara, 26 Agustus 2020)

"Poligami dibolehkan dalam Islam. Setiap orang punya masalah dan kebutuhan yang berbeda dalam memehuhi hajat masing -masing. Bisa jadi untuk sebagian keluarga poligami membawa petaka dan lain halnya untuk sebagian keluarga lainnya justru menjadi solusi." (IM, wawancara, 27 Agustus 2020)

"Memang benar poligami dibenarkan dalam agama Islam, untuk menghindari perbuatan maksiat, namun ketika laki-laki melakukan poligami, tidaklah semuanya adil, dan ada beberapa sebagian bahkan tidak dipenuhi nafkah lahir maupun batin." (MN, wawancara, 24 Agustus 2020)

Terkait dengan konteks keadilan dalam implementasi hukum poligami tersebut, sebagian besar informan memiliki persepsi bahwa keadilan itu akan sulit diterapkan walaupun Qanun Poligami telah dilegalkan. Hal ini diperkuat dari diagram di bawah ini yang secara mayoritas menyatakan penolakan perempuan bahwa penyusunan qanun poligami bertujuan agar lakilaki dapat berbuat adil kepada perempuan. 


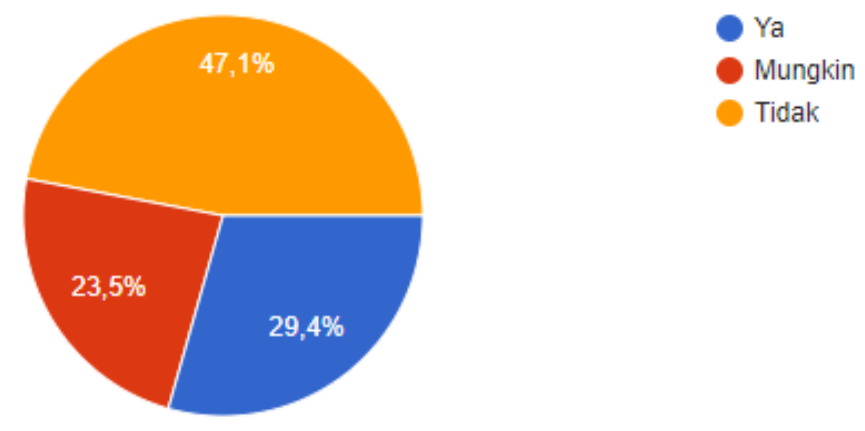

Gambar 1. Persepsi Tujuan Pelegalan Poligami Agar Laki-Laki Memberikan Keadilan

Pada sisi lainnya, sebagian besar responden masih ragu bahwa kehadiran Qanun Pelegalan Poligami tersebut dapat menjadi solusi perlindungan hak-hak perempuan dan anak dalam keluarga. Hal ini dapat dilihat dalam diagaram di bawah ini.

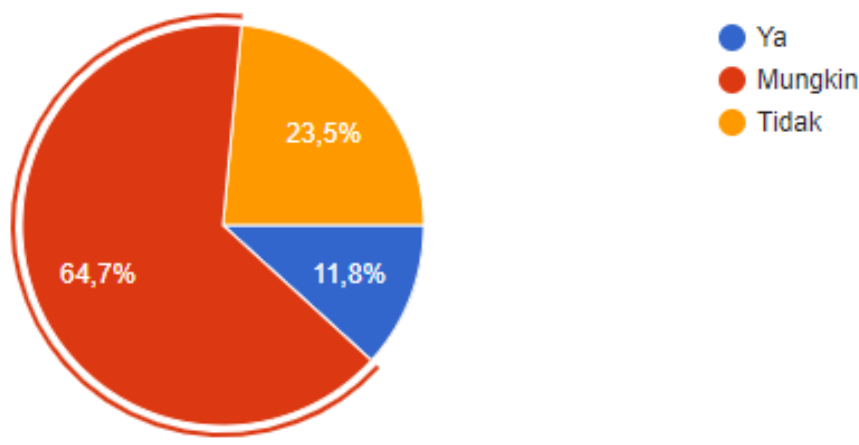

Gambar 2: Qanun Poligami Sebagai Solusi Perlindungan Perempuan

Sedangkan dari hasil wawancara seluruh informan didapatkan kesimpulan bahwa terdapat kemungkinan bahwa Qanun Pelegalan Poligami tersebut dapat menjadi solusi perlindungan hak-hak perempuan dan anak dalam keluarga namun hal ini masih sulit dibuktikan karena perlindungan erat kaitannya dengan keadilan dan untuk mengukur adil ini sifatnya sangat relatif dan tentatif. Qanun ini dianggap akan melindungi hak-hak istri kedua dan anaknya namun di sisi lain melukai perasaan istri pertama.Hal ini jelas tergambarkan dari keraguan mayoritas responden dalammemandang keberadaan Qanun Poligami tidak akan menyudutkan dan tidak akan merugikan perempuan. Sebagian besar mereka menyatakan mungkin saja qanun tersebut tidak menyudutkan dan merugikan perempuan. 


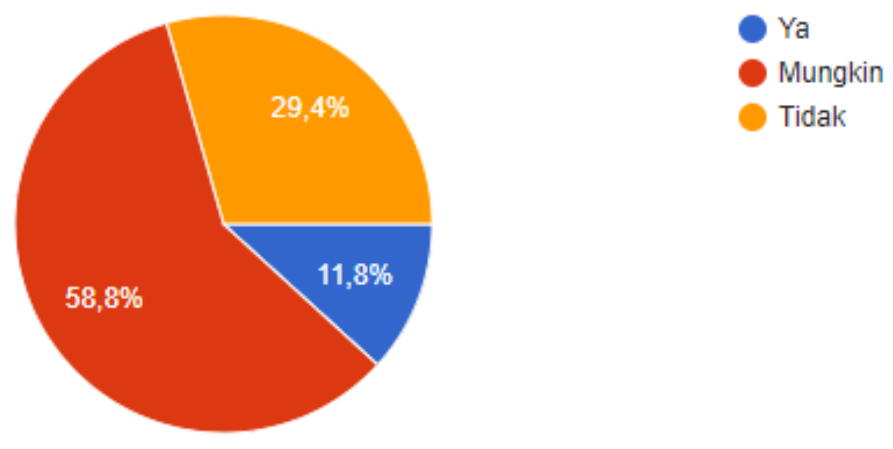

Gambar 3 : Qanun Poligami Tidak Menyudutkan Perempuan

Keraguan mereka juga dipengaruhi oleh pandangan mereka tentang kesiapan pemerintah dalam menyusun Qanun Poligami ini. Sebagian besar informan menyatakan bahwa pemerintah belum siap dalam menyusun qanun tersebut.

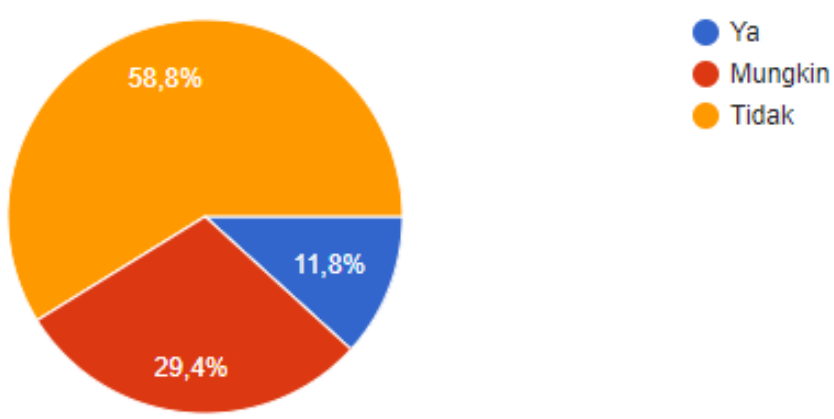

Gambar 4: Kesiapan Pemerintah Terhadap Pelegalan Qanun Poligami

Kehadiran qanun poligami ini dianggap tidak diperlukan oleh sebagian besar responden. Mereka beranggapan bahwa pemerintah seharusnya fokus kepada qanun-qanun lainnya yang lebih penting dikarenakan peraturan poligami sendiri telah ada dalam agama sehingga tidak perlu lagi dilegalkan secara hukum.

"Saya hanya heran, kenapa mesti ada yang namanya pelegalan poligami? Bukankah poligami itu di dalam Islam adalah legal? Dan juga masyarakat kita sudah banyak yang melakukannya jauh sebelum rencana pelegalan ini ada. Saya menganggap bahwa usaha pelegalan ini hanya satu usaha yang akan dijadikan alasan bagi lakilaki untuk berpoligami tanpa dihantui rasa bersalah." (DS, wawancara, 24 Agustus 2020)

"Saya bukan pengikut untuk menyetujui qanun ini berlaku karena pada implementasinya akan menimbulkan kekacauan atau ketidakstabilan dalam hal yang lain." (PK, wawancara, 28 Agustus 2020)

"Hal yang sudah diatur jelas oleh agama tidak perlu diatur lagi dalam aturan perundang-undangan." (RL, wawancara, 29 Agustus 2020) 
Namun ada sebagian responden yang memberikan pandangan bahwa qanun poligami ini penting agar dapat menyelesaikan persoalan maraknya nikah siri di Aceh.

"Tentunya setiap kebijakan harus melalui kajian sebelumnya, dan tentunya tidak semua orang bisa menerima kebijakan itu begitu saja, walaupun secara kaidah sudah diatur mengenai poligami. Tapi saya cukup mengapresiasi Pemda Aceh terhadap maraknya nikah siri yang terjadi di Aceh. Semoga kebijakan ini bukan hanya sekedar formalitas pengeluaran anggaran tetapi benar-benar dikaji untuk membantu penyelesaian masalah yang ada di masyarakat." (AD, wawancara, 25 Agustus 2020)

Namun sebagian besar responden masih meragukan pelegalan poligami dapat menyelesaikan masalah dan menjadi solusi untuk mengurangi nikah siri yang marak terjadi di masyarakat. Hal ini tergambarkan pada hasil penelitian yang menyatakan bahwa mayoritas responden menyatakan mungkin untuk kasus tersebut dan dapat diartikan mereka memiliki keraguan hal ini dapat terjadi.

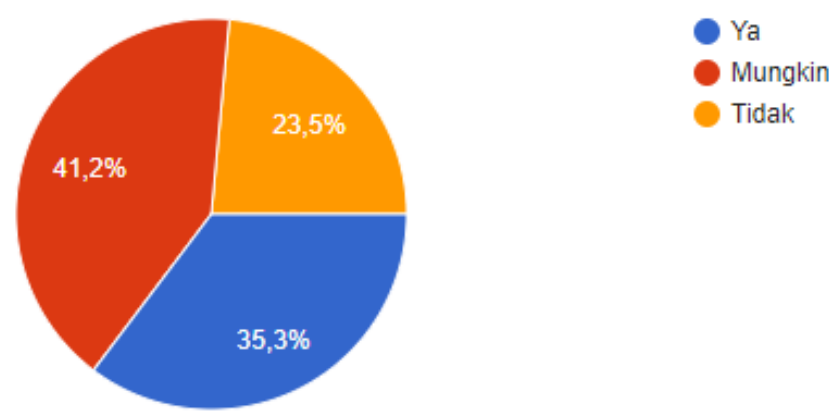

Gambar 5: Poligami Sebagai Solusi Pernikahan Siri

Jika dikaji dalam konteks lainnya, faktor struktural juga menjadi salah satu penyebab kesamaan persepsi yang diberikan oleh sebagian besar responden perempuan. Hampir keseluruhan responden menyatakan tidak jika suaminya memutuskan untuk berpoligami. Namun apabila dinilai dari sisi ibadah, sebagian kecil mereka beranggapan harus siap namun apabila mereka sudah tidak mampu menjadi istri yang ideal bagi suami mereka.

"Untuk saat ini saya tidak siap dipoligami tapi jika suatu saat saya punya keterbatasan dalam memerankan peran sebagai isteri maka saya akan mempersilakan suami untuk berpoligami. Semoga Allah memberi kekuatan dan kesehatan dalam menjalankan tugas sebagai istri dan ibu." (IM, wawancara, 27 Agustus 2020)

"Secara nurani seorang wanita tentu tidak siap, namun karena syariah membolehkan poligami, maka selama itu dijalankan sesuai dengan syariat, saya ridha dengan mengharapkan keridhaaan Allah." (DM, wawancara, 26 Agustus 2020)

Kesamaan persepsi perempuan terhadap implementasi poligami atas diri mereka sendiri menunjukkan apa yang dijelaskan oleh Krech dan Crutchfield bahwa individu cenderung dalampengelompokan stimulus dari kesamaan dan kedekatan universal. Kesamaan bahwa perempuan tidak ingin dinomorduakan, tidak siap secara mental, dan pengalaman yang sama atas rasa ketertindasan menjadi motivasi untuk menolak poligami terhadap diri mereka sendiri. 
Kotler dalam Twentinio (2013:14) menyatakan bahwa alasan mengapa perempuan mempunyai keberagaman sudut pandang dalam memaknai wacana pelegalan poligami di Aceh sebagai objek stimulus yang serupa dikarenakan tiga tahapan persepsi antara lain:

1.) Perhatian Selektif. Perempuan memeperoleh banyak stimulus dari luar dirinya yang berhubungan dengan kasus-kasus poligami, baik di lingkungannya atau dari terpaan informasi yang didapatkannya di media massa sehingga cenderung menarik perhatiannya. Perhatian adalah proses mental ketika stimulus atau rangkaian stimulus menjadi menonjol dalam kesadaran dan ketika stimulus lainnya melemah. Terpaan informasi pelegalan poligami di media massa yang dipublikasikan berulang kali akan menarik perhatian perempuan dan mengkaitkan dengan faktor internal yang dimilikinya dalam mempersepsi pesan atau informasi;

2.) Distorsi Selektif. Ketika perempuan memiliki kecendrungan menafsirkan informasi sehingga sesuai dengan prakonsepsi yang dimilikinya. Sehingga makna poligami akan dipersepsikan dengan keyakinan awal yang dimilikinya dan yang kepentingannya.

3.) Ingatan Selektif.Perempuanakan lupa pada hal-hal yang telah mereka pelajaridan mereka temukan di lapangan terkait dengan permasalahan poligami tersebut, namun disebabkan terdapat ingatan selektif maka perempuan akan lebih mengingat hal-hal tertentu yang menurutnya menarik atau justru tidak baik tentang poligami.

Jika dikaitkan kembali dengan spiral keheningan, opini kalangan perempuan terhadap wacana pelegalan poligami di Aceh dipandang menunjukkan bagaimana konsep spiral keheningan tersebut diimplementasikan. Pada karakteristik pengetahuan, masyarakat Aceh khususnya kalangan perempuan di Aceh mengetahui secara jelas wacana yang dibincangkan oleh media dan pemerintah. Ditambah lagi dengan adanya kerangka rujukan yang dimiliki oleh informan penelitian tentang referensi poligami baik secara agama ataupun kaidah hukum. Sedangkan jika dilihat pada karakteristik kedekatan, isu poligami merupakan hal yang dekat dengan keseharian khalayak terutama bagi informan penelitian yang sudah menikah. Sehingga opini perempuan yang ditemukan dari hasil penelitian, menunjukkan perhatian mereka terhadap isu poligami karena hal tersebut dapat saja menjadi pengalaman dari hidupnya sendiri. Pada karakteristik lainnya, khalayak dapat memprediksi opini secara jelas bahwa arah wacana pemerintah terkait pelegalan poligami sebagai opini mayoritas yang berkembang di masyarakat. Kuasa pemerintah melalui legitimasi kebijakan dan dominasi wacana di mediamedia massa menjadi suara yang mendominasi dan secara tidak langsung mendorong khalayak sebagai pihak yang 'asing' untuk dapat menyuarakan pendapat mereka.

\section{KESIMPULAN}

Persepsi kalangan perempuan di Aceh terkait pelegalan hukum poligami merupakan bagian dari suara khalayak media yang memberikan realitas berbeda dengan apa yang ditampilkan oleh media pada umumnya. Ketidaksiapan perempuan terhadap implementasi poligami pada dirinya, keraguan atas keadilan dari kebijakan poligami jika diterapkan, pengalaman personal atas realita pernikahan poligami yang diketahuinya berpengaruh terhadap opini perempuan terhadap pelegalan poligami di Aceh. Persepsi perempuan tersebut dalam konteks spiral keheningan adalah bentuk heningnya khalayak atas realitas opini yang dibangun pemerintah tentang kelayakan dari pelegalan poligami di Aceh sebagai suatu solusi dari kasus-kasus pernikahan di Aceh. Pendapat khalayak tentang pelegalan poligami ini dapat menjadi pijakan, bagaimana poligami belum sepenuhnya dapat diimplementasikan sebagai suatu qanun resmi di Aceh jika ingin menyelesaikan persoalan. Pemerintah perlu memerhatikan kembali suara dari khalayak, terutama kalangan perempuan sebagai pihak yang menjadi objek dari implementasi poligami untuk kajian lebih lanjut terhadap kelayakan dan ketepatan kebijakan qanun dalam mengatur permasalahan pernikahan di Aceh. 


\section{DAFTAR PUSTAKA}

\section{Buku:}

Aceh Tribun News. (2020). Perceraian Wanita Aceh. (https://aceh.tribunnews.com/2020/07/27/perceraian-wanita-aceh. Diakses 10 Oktober 2020).

Ahmad, W. S. (2013). Status Poligami Dalam Hukum Islam (Telaah atas Berbagai Kesalahan Memahami Nas dan Praktik Poligami). Jurnal Al Ahwal, 6 (1), 57-70.

Ambon, G. (2014). Marjinalisasi Perempuan Dan Dominasi Laki-Laki Terhadap Perempuan Dalam Drama Faust I Karya Johann Wolfgang Von Goethe: Kritik Sastra Feminis. Skripsi. Universitas Negeri Yogyakarta.

Darmawijaya, E. (2015). Poligami dalam Hukum Islam dan Hukum Positif: Tinjauan Hukum Keluarga Turki, Tunisia dan Indonesia. Jurnal Gender Equality: International Journal of Child and Gender Studies, 1 (1), 27-38.

Desiderato, D.B. Howeison. \& J.H. Jackson. (1976). Investigating Behaviour: Principles of Psychology. New York: Harper \& Row Publisher.

Farid, M. (2017). Hegemoni Patriarki Dalam Poligami Kiai Di Madura. Thesis. Universitas Airlangga.

Ghazaly, A. R. (2006). Fiqih Munakahat. Jakarta: Kencana.

Israpil. (2017). Budaya Patriarki dan Kekerasan Terhadap Perempuan (Sejarah dan Perkembangannya). Jurnal Pusaka, 5 (2): 141-150.

Kotler, P. (1993). Manajemen Pemasaran, Perencanaaan, Implementasi dan Kontrol. Jakarta: PT. Rosdakarya.

Kotler, P., \& Kevin L. K. (2009). Manajemen Pemasaran. Edisi 12.Terjemahan Bob Sabran. Jakarta: Erlangga.

Littlejohn, S. W., \& Foss, K. A. (2009). Teori Komunikasi: Theories of Human Communication. Edisi 9. Jakarta: PT. Salemba Humanika.

Rakhmat, J. (2011. Psikologi Komunikasi). Bandung: PT. Remaja Rosdakarya

Schiffman, L. G. \& Kanuk, L. L. (2004). Cunsomer Behaviour. New Jersey: PrenticeHall.

Thoha, M. (2004). Perilaku Organisasi, Konsep Dasar dan Aplikasinya. Jakarta: Raja Grafindo Persada.

Zuhrah, F. (2010). Problematika Hukum Poligami Di Indonesia: Analisis Terhadap UU No. 1 Tahun 1974 Dan KHI. Jurnal Al-Usrah. http://jurnal.uinsu.ac.id/index.php/alusrah/article/download/1342/1089 (diakses 